\title{
Thoughts on ISO and the Development of Terminologies in Southern Africa ${ }^{1}$
}

\author{
C.J. Scheffer, National Terminology Services, Department of National \\ Education*
}

Abstract: A South African national committee of ISO's Technical Committee 37 was established during 1990. This national committee is the link between South African bodies who develop and standardise terminologies and ISO committees who standardise terminologies with a view to the quality control of products. In this article the aims of the national committee as well as an overview of resources that can help to achieve the objectives of the committee are presented. ISO has already consented to a request of the national committee that ISO and related terminological data may be put on the National Termbank (NTB). The display of this type of information on the NTB is discussed, as well as the implications for the adapting of lexical databases based on the information needs of developing societies. The advantages of the existing national facilities for users of terminologies and other lexical data as well as the effectiveness brought about by one system to exchange such data nationally and internationally are also emphasised. The implications of language policy decisions on the development of technical languages, terminologies, general lexicography and the dissemination of information will also require special attention in a new South Africa.

Keywords: STANDARDISATION, TERMINOLOGY, TECHNICAL LANGUAGE, TERMBANK, LEXICAL DATA, NETWORKS, INTERNATIONAL DATA EXCHANGE, ISO, TECH-NICAL COMMITTEE, QUALITY CONTROL, CONCEPTS, GENERAL LEXICOGRAPHY, AFRICAN LANGUAGE CODES

\section{Opsomming: Enkele gedagtes oor ISO en die ontwikkeling van terminolo-} gieë in Suidelike Afrika. Gedurende 1990 het 'n Suid-Afrikaanse nasionale komitee van ISO se Tegniese Komitee 37 tot stand gekom. Hierdie komitee dien as skakel tussen SuidAfrikaanse instansies wat terminologieë wil standaardiseer en ISO wat terminologie standaardiseer met die oog op kwaliteitsbestuur van produkte. In die artikel word die oogmerke van die nasionale komitee ulteengesit asook die hulpmiddele wat kan bydra om sy doelwitte te bereik. ISO het reeds toegestem dat begrippe en die terme wat dit benoem, op die Nasionale Termbank (NTB) geplaas mag word. Die wyse waarop terminologie-inligting wat bv. 150 verskaf, op die NTB vertoon kan word, word bespreek, asook die implikasie wat dié ontwikkelende gemeenskappe se inligtingsbehoeftes vir die aanpassing van leksikale databasisse inhou. Die voordeel wat die bestaande nasionale fasiliteite vir gebruikers van terminologieë en ander leksikale data inhou, asook die effektiwiteit wat een stelsel meebring om data nasionaal en internasionaal uit te ruil, word ook beklemtoon. Die implikasies van taalbeleidsbesluite op die ontwikkeling van vaktale, 
terminologieë, die algemene leksikografie en inligtingsverspreiding sal in 'n nuwe Suid-Afrika spesiale aandag verg.

Sleutelwoorde: STANDAARDISERING, TERMINOLOGIE, VAKTAAL, TERMBANK, LEKSIKALE DATA, NETWERKE, INTERNASIONALE DATA-UITRUILING, ISO, TEGNIESE KOMITEE, KWALITEITSBESTUUR, BEGRIPPE, ALGEMENE LEKSIKOGRAFIE, AFRIKATAALKODES

\section{Introduction}

The following observations are relevant to the objectives pursued in this article:

(a) International co-operation and exchange of information by international scientific and technical communities have been facilitated by an improved political attitude towards South Africa.

(b) Information exchange by way of technological means such as computers has implications for the elaboration of languages and their use in special contexts e.g. in quality management by standards organisations.

(c) The advantages of quality control of products can often be explained to different groups by also using the lower registers of technical languages and by simplifying texts.

(d) Language is a natural means of ordering and classifying information.

(e) The standardisation of concepts as well as the terms naming them is an integral part of standards documents produced by standards organisations.

In pursuance of their objectives the International Standardization Organization (ISO), the International Electrotechnical Commission (IEC) and other standards organisations have in general developed fairly established committees and working methods, with the necessary documentation resulting from these activities. ISO documentation, for example, covers working documents $(\mathrm{N})$, technical reports (TR), recommendations (R), draft proposals (DP), draft international standards (DIS) and international standards (IS). These documents are compiled by technical committees (TCs), their subcommittees (SCs) and workgroups (WGs). The ISO technical committee chiefly concerned with terminology is TC37.

\section{Objectives}

For the purposes of this article the following objectives are set:

(a) To determine what the relationship between the National Committee 
of ISO TC37 (in South Africa) and ISO can or should be.

(b) To provide information on the objectives and functions of the National Committee.

(c) To identify resources that can support the National Committee in achieving its objectives.

(d) To demonstrate how the standards information may serve e.g. the translator, technical writer and science journalist.

\section{Perspective on the task of the National Committee}

The co-ordination and standardisation of terminologies by ISO's TC37 is a support function in order for ISO to issue clear and unambiguous standards. It follows that the description of concepts in particular contexts is not a line function as such, but a very important staff function.

This National Committee is in the first instance internationally aimed at supporting ISO and participating in the activities of the subcommittees concerned.

Participation in the activities of an international community must to a certain extent also profit at national level, such as the supporting of national objectives in South Africa (this involves bringing about prosperity; improving intergroup relations and promoting technological innovation).

\section{Objectives and functions of the National Committee in South Africa}

At the first meeting of the National Committee the objectives of the Committee were formulated in terms of its broad mission viz. to participate at international level in the activities of TC37 and to promote standardisation of terminologies in South Africa on the basis of the principles subscribed to by ISO.

The objectives of the National Committee are to promote scientific and technical communication in South Africa, in particular through the development of standardised terminologies in fields of study or fields of activity where such a need exists.

The Committee has already identified the following tasks:

(a) Collecting already systemised and standardised terminologies.

(b) Providing English terminological data, in particular, for entry into the National Termbank (NTB).

(c) Promoting the use of the NTB.

(d) Liaising with language organisations.

(e) Propagating the benefits of standardising computer formats, procedures and methodology with regard to technical language activities and products throughout South Africa. 
(f) Determining needs for standardised terminologies and needs in relating spheres.

(g) Collecting information on how terminological issues are dealt with in, e.g. the European Economical Community. In addition to this, how and what types of tasks other national committees of TC37 undertake.

(h) Attending overseas meetings, seminars, conferences, etc.

The Committee is of the opinion that high priority should be given to the communication needs of the different technical and other communities regarding standardised terminologies. The Committee will therefore act in a facilitating capacity with regard to information dissemination and problemsolving.

Standardisation should, as far as possible, occur on the basis of consensus. This can be achieved by, amongst other things, co-opting bodies with an interest in a particular field of study, and who may possibly make some contribution.

The Committee will go through an orientation phase initially and participate in the activities of ISO TC37 by commenting on draft documents and by identifying information of national significance.

A draft list of international language codes titled Alpha 3 (based on the use of three letters of the alphabet) was studied and compared with ISO 639 (an international two-letter code list). Certain omissions with regard to the African languages came to the fore. Prompted by these findings proposals were put forward to the convenor of the relevant technical committee as a first contribution by the National Committee.

Examples of African language codes with two and three characters (based on a general principle laid down by die relevant technical committees) are the following:

$\begin{array}{llll}\text { Zulu } & : & \text { zu } & \text { zul } \\ \text { Swazi } & : & \text { ss } & \text { ssw } \\ \text { Tswana } & : & \text { tn } & \text { tsn } \\ \text { Tsonga } & : & \text { ts } & \text { tso } \\ \text { Xhosa } & : & \text { xh } & \text { xho } \\ \text { South Sotho } & : & \text { st } & \text { sot }\end{array}$

At national level every endeavour will be made to disseminate English standardised terminologies and definitions as soon and as widely as possible in order to undertake, as the need arises, lexical development with respect to indigenous languages. ISO has already consented to making available technical language information, developed by ISO's TCs, to the National Termbank. 


\section{Potential resources for use by the National Committee}

The following can already be identified roughly:

\section{(a) Literature in relevant spheres}

In addition to ISO documents and those of other standards organisations much has been published internationally and locally on theories of technical language and terminology; technical language development and its role in the development of standard languages; proliferation of terminologies and the limitations and problems in standardising terminologies. In the technical language report prepared by Cluver and Scheffer (1984) a number of problems were identified regarding the technical language practice in South Africa. Among these resort: a production problem; a training problem; a dissemination problem and a standardisation problem.

With regard to the training problem the National Terminology Services (NTS) has for example joined hands in compiling a manual of terminography as well as making available guideline documents and manuals of methodology (compare Cluver 1989a and b; Scheffer 1986 and Department of National Education 1989 and 1991).

Attempts to deal with certain standardisation problems will be made through the National Committee of ISO TC37.

With regard to the problems concerning the production and dissemination of terminologies, the NTS implements the technical language model proposed in 1984, with the rationale for decentralised production where possible and for the documentation of terms at the point of origin or source. The centralised information in the NTB then serves as basis for the creation of different types of lexicographical and other technical language products whereby terminology can be disseminated countrywide as well as standardised after consensus has been reached amongst technical language users and after further processing. See Appendices A and B.

In order for the model to succeed it is important that terminology be submitted to the NTB and that information on technical language and other projects be communicated to the NTS (e.g. the registration of projects with a view to assistance and co-ordination of activities).

Professional specialist and language organisations which can make specific contributions

The value of e.g. the latest Afrikaanse Woordelys en Spelreêls (1991) for use by editorial committees of technical dictionaries and/or the acceptable final preparation of technical language information for databases is self-evident. The assistance rendered by e.g. The English Academy of Southern Africa in 
solving writing problems is indispensable. Networks of experts in various fields will also support the standardisation action.

An essential network in the modern information society is SABINET who renders bibliographical and other information services to all sectors of the economy. SABINET was also one of the first organisations to link into the NTB.

\section{(c) National Termbank}

The focal point of the technical language model proposed in the technical language report of 1984 is the computerised central terminological database - the National Termbank - which is administered by the NTS for the convenience and benefit of all technical language users.

Various classifications for describing termbanks have already been drawn up. One very common classification is the differentiation between dictionary banks and vocabulary banks, with the latter serving as aid for concept and term standardisation as well as for providing technical language users, with various types of products.

The NTB is structured in such a way, however, that it conforms to the needs of a diversity of technical language users in that the user can generate a wide range of products from the database. The NTB accommodates technical language information from all walks of life, fields of study and disciplines, is conceptually-oriented and multilingual by nature. ${ }^{2}$

Appendix $C$ portrays the basic layout of the structure. In practice an entry is presented as shown in Appendix D.

The editorial committee of this dictionary had not only made every effort to fully illustrate the concepts by including concise context indicators, e.g.

recall v. : terugroep (persone)

recall v. : herroep (argumente)

but also, for example, by placing the synonyms in the target language in order of preference as follows:

public property : : staatseiendom, openbare eiendom, publieke eiendom.

(This layout does not apply to a converted list where each synonym in the target language is in turn recorded as headword.)

Indicating orders of preference can be looked upon as the forerunner of term standardisation.

ISO's term information, together with information on the degree of acceptability of a particular term, can also be entered in the Termbank. The levels of acceptability as seen in Appendix $E$ are recorded as context indicators 
after the headword or lemma (Gouws 1989: 36), see Appendix C.

Appendix $F$ serves as a representation of an entry compiled from ISO information. Such an entry indicates clearly that the definition is contextrelated and that the status of the term is determined by a number of factors such as acceptability (Appendix E); the status of the source document or of the publication as well as by additional contextual information.

Even though the data of ISO and other standards organisations seem to be in the formal register primarily, it is important that the NTB be provided with data in all registers, even without the possibility of standardising such data. Should a termbank also be utilized as information bank (and knowledge bank) it must be possible to disseminate information through lexical information in all relevant registers. This implies that additional data such as synonyms in various registers will be recorded on the database of the NTB.

At the same time a termbank such as the NTB and its network of collaborators are also under the obligation to support professional training and attempts made at the upgrading of work literacy. A significant implication of such a challenge is that more of the information categories on the Termbank will have to be utilized and that new categories and relationships between information categories will have to be determined.

These information categories on a computerised lexical database would also include such categories that would accommodate data from the more informal subjects and work spheres, for example, advertising, marketing and computer jargon. Such a spectrum of information categories will include the naming of concepts in everyday language.

The computer systems and facilities supporting the NTB therefore cater for the needs of general lexicographers as well. With a view to the international exchange of lexical data (be it of a technical or general nature) the systems offered by the Department of National Education are geared to the effective writing of data to formats which will be acceptable not only to other ISO members but also to other dictionary units in Africa and overseas. The advantage of having one system to locally process and then address a multitude of terminographical and general lexicographical products and inputs to overseas and local distributors like Beltel goes without saying.

\section{Closing remarks}

It appears from ISO documentation that a considerable amount of work has already been done in the field of unification and standardisation of concepts and terms (compare ISO/R860-1968E). Also in South Africa a number of works have been published on standards, terminography, technical language theory, etc. (compare Cluver 1987; 1988; 1989a; 1989b; Swanepoel 1990).

The NTS has already made considerable progress with the standardisation of computer formats, procedures, systems and the writing of documents on 
methodology. These facilities are available to the public. Computer linkage to the systems of other overseas communities is already a reality. The application and utilization of the facilities and structures are, however, attitude-dependent and need-driven to a large extent.

The future position of English seems secure within the ISO context. To what extent indigenous languages will be involved in the process of internationalisation will be determined by external linguistic factors such as a new political dispensation, language and culture policy and a new education policy. The systems described above will be able to accommodate the results of any policy decisions, but probably not without specific new implications for the task of role players in the technical language practice of the future.

Language planners and policy makers are at present looking into language policy models that may influence participation in the activities of ISO and other standards organisations.

Hopefully TC37's National Committee will contribute to the effective flow of scientific technical information in South Africa especially in the field of language modernisation and standardisation. The implications this may have on the prosperity of the community and on technological innovation are self-evident.

\section{Notes}

- Translated by E.C. Nothnagel, BA Hons. (Linguistics), Diploma in Translation.

1 Based on a preliminary address at the first meeting of the National Committee, Friday 26 October 1990 at the SABS in Pretoria.

2 The database is being improved to more effectively meet the needs of general lexicographers.

\section{References}

\section{Dictionary}

Cluver, A.D. de V. 1989. Dictionary of Terminography/Terminografiewoordeboek. Pretoria: Human Sciences Research Council.

\section{Other sources}

Cluver, A.D. de V. 1987. A Sociolinguistic Approach to the Study of Technical Languages. Logos 7(2): $13-30$.

Cluver, A.D. de V. 1988. Towards a Post-positive Model of Technical Languages. Termnet News 20. 1-10. 
Cluver, A.D. de V. 1989a. A Manual of Terminography. Pretoria: Human Sciences Research Council.

Cluver, A.D. de V. 1989b. Die rol van vaktaal in die ontwikkeling van standaardtale. Botha, T.J.R. (Ed.). 1989. Leksikologie en Leksibografie. Pretoria: Serva.

Cluver, A.D. de V. and C.J. Sch effer (Eds.). 1984. RGN-ondersoek na vaktaalaangeleenthede in Suidelike Afrika; verslag van die ondersoek na organisatoriese aangeleenthede op vaktaalgebied. Pretoria: Human Sciences Research Council.

Department of National Education. National Terminology Services. 1989. Assistance with regard to Terminology Projects. (NATED 08-003 (89/10)). Pretoria: Department of National Education.

Department of National Education. National Terminology Services. 1991. Lexikon Computer Program: Program and Dictionary Methodology Manuals. (NATED 08-005 (91/01)). Pretoria: Deparment of National Education.

Gouws, R.H. 1989. Leksikografie. Pretoria: Academica.

International Organization for Standardization. 1968. International Unification of Concepts and Terms. (ISO/R860-1968E). Genève: International Organization for Standardization.

International Organization for Standardization. 1988. Codes for the Representation of Names of Languages. (ISO/639-1988) Genève: International Organization for Standardization..

Scheffer, C.J. 1986. Enkele oorwegings by die saamstel van 'n vakwoordeboek. Die SuidAfritaanse Tydskrif vir Natuurusetenskap en Tegnologie 5(3): 161-164.

Scheffer, C.J. 1987. Promoting and Managing Terminological Activities in South Africa. Logos 7(2): 31-34.

Swanepoel, P. 1990. Definisies in vakkommunikasie. Pretoria: Human Sciences Research Council. 


\section{FLOW OF TECHNICAL LANGUAGE INFORMATION IN A DEVELOPING COMMUNITY}

Note: Creators and users of technlcal language information are indicated respectively on the Input and the output side of the system deseription

Translators Language editors

Language service, DNE

development of

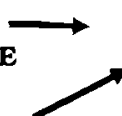

domestic languages)

Currtculators, DNE

SABC, Academy

administration, Industry

publishers, Politicians

Mass media

Interpreters (in courts,

conferences)

Tedinical writers

(tenders and specificatlons)

Standards organisations

Information experts/documen-

talists eg archivists

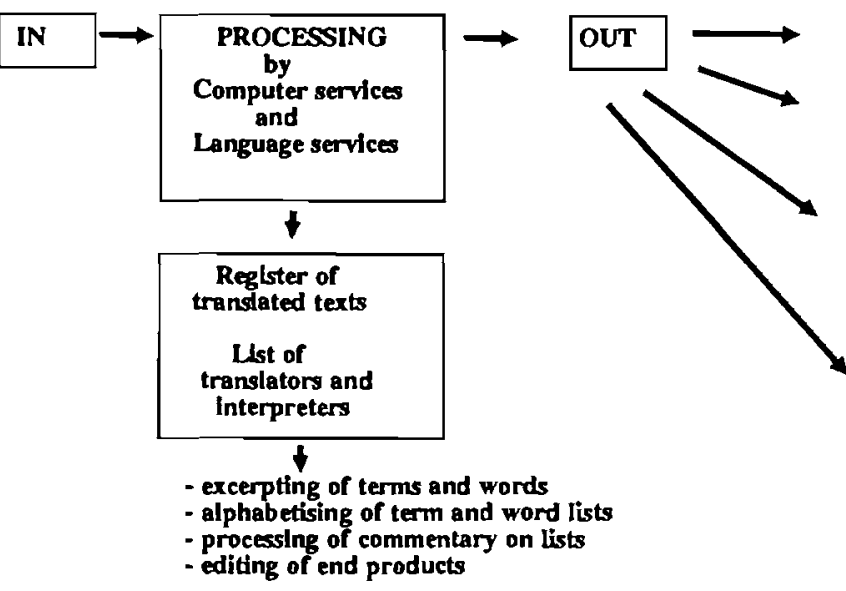

End products

to users:

- dietionaries

- glossartes

- thesourt

Spelling llsts and orthographies

Termbank

Textbank with

headwords

(documents with

headwords)

Information in:

- curriculae

- literature

books

- textbooks

- directions for

use

- techinical

Joumals

- annual reports 
SYSTEMS APPROACH BY THE NTS TO TERMINOLOGY WORK

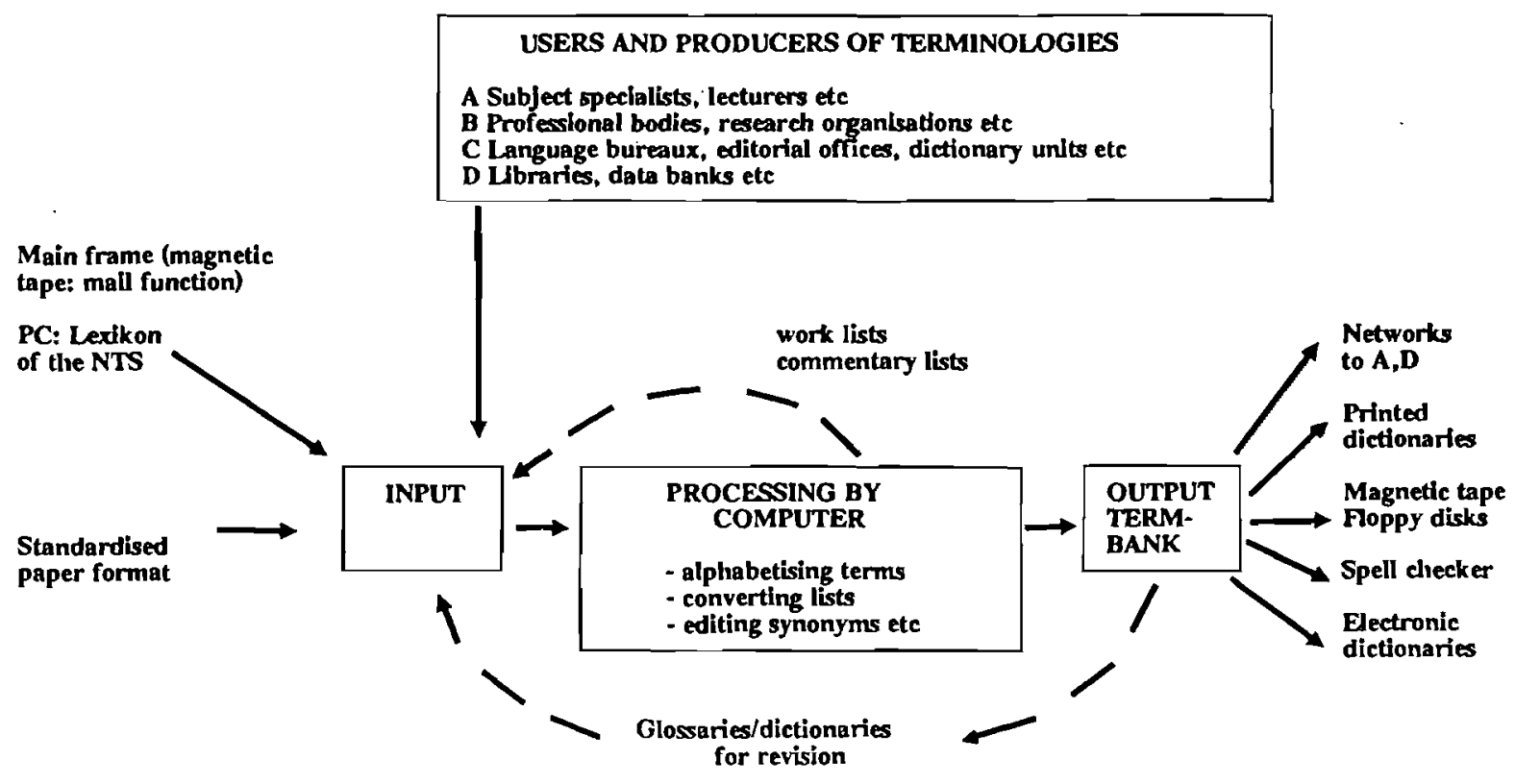




\section{Appendix C}

\section{PARAGRAPH NAMES ON NATIONAL TERMBANK}

(A new database is being developed)

1. DOCUMENTNO

2. CONCEPT CODE

3. TERM

4. WORD CLASS

5. DATE

6. SYNONYM

7. EQUIVALENT

8. GREEK/LATIN

9. TABBREVIATION

10. EABBREVIATION

11. $\mathrm{CF}$

12. DEFINITION

13. USAGE

14. BROADER TERM
15. NARROWER

16. RELATED TERM

17. REGISTER

18. SYLLABLES/MORPHOLOGY

19. RESEARCH

20. TERM LANGUAGE

21. EQUIV ALENT LANGUAGE

22. SOURCE INFO

Primary Source

Secondary Source

23. PUBLICATION

24. SUBJECT CODE

25. STATUS

26. SRC 


\section{Appendix D}

\section{EXAMPLE OF ENTRY ON NATIONAL TERMBANK}

DOCNR

TERM

EQ

$\mathrm{CF}$

DEFINE

SYLLMORPH

TERMLANG

EQLANG

SOURCINFO

PUBL

SUBJCODE

STATUS
00063587

absolutism

absolutisme

totalitarianism

The principle or practice of a political system in which a monarch, dictator, etc has unlimited powers. SYLL: ab - so - lut - ism

MORPH: Complex word; absolute $\mathrm{x}$ ism. This abstract $\mathrm{N}$ is formed from the Adv root \{absolute\} and the derivation suffix -ism.

En

Af

DOCLANG: En

POLITICAL AND RELATED TERMINOLOGY/STAATKUNDIGE EN VERWANTE TERMINOLOGIE (1988)

National Terminology Services, Department of National Education, Pretoria: Government Printer / Nasionale Vakterminologiediens, Departement van Nasionale Opvoeding, Pretoria: Staatsdrukker 220501

STANDARDISED; COMMITTEE; INSTITUTION; PRELIMINARY PROCESSED / GENORMEER; KOMITEE; INSTELLING; VOORLOPIG VERWERK. 


\section{Appendix E}

\section{EVALUATION OF TERMS}

preferred term: admitted term:

deprecated term/ rejected term: obsolete term:

ISO/DIS 1087 term recommended by an authoritative body. term accepted as a synonym for a preferred term by an authoritative body.

term rejected by an authoritative body. term which is no longer in use.

\section{Appendix F}

\section{EXAMPLE OF ISO INFORMATION ON TERMBANK}

DOCNR

TERM

EQ

CF

DEFINE

SYLLMORPH

TERMLANG

EQLANG

SOURCINFO

PUBL

SUBJCODE STATUS
013479

text corpus

tekskorpus

text

A systematic collection of machine-readable data, texts or parts of text, representing a specific text universe and prepared, coded or sorted according to predefined rules.

En

Af

DOCLANG : En SECOND SOURCE : SABS

ISO/TC 37/SC 3 N 58 en. Working draft for Technical Report. "Computer aids in terminology" (revised edition of ISO/TC 37/SC $3 \mathrm{~N} 44 \mathrm{en).}$

UDC 001.4

COMMITTEE; Preliminary processed. $(\mathrm{N}=$ working document.) 